\title{
Fluorescence Imaging System Using High Power LED to Generate Oral Auto-fluoerscence of Sprague dawley Rat
}

\author{
Lailis Sa' ${ }^{\prime}{ }^{1}{ }^{1}$, Frida Agung Rakhmadi ${ }^{1}$, Rini Widyaningrum ${ }^{2 *}$ \\ ${ }^{1}$ Physics Department, Faculty of Science and Technology, UIN Sunan Kalijaga Yogyakarta \\ Jl. Marsda Adisucipto No 1 Yogyakarta 55281, Indonesia. Tel. +62-274-540971, Fax. +62-274-519739. \\ ${ }^{2}$ Department of Dentomaxilofacial Radiology, Faculty of Dentistry, Universitas Gadjah Mada, \\ Jl. Denta Sekip Utara, Bulaksumur, Yogyakarta 55281, Indonesia. Tel/Fax. +62-274-515307. \\ *Email: rinihapsara@ugm.ac.id
}

\begin{abstract}
Sa'adah L, Rakhmadi F A, Widyaningrum R. 2017. Fluorescence Imaging System Using High Power LED to Generate Oral Auto-fluoerscence of Sprague dawley Rat. Proc Internat Conf Sci Engin 1: 161-167. It is difficult to distinguish oral cancer and normal oral mucosa in clinical examination. Hence, it is important to develop a diagnostic tool to aid clinical practitioners to examine and diagnose abnormalities in oral cavity. One of methods applied for this purpose was based on tissue auto-fluorescence. The purpose of this study was to develop a fluorescence imaging (FI) system using High Power LED (HPL) as excitation source. There were 3 HPL with different wavelengths used in this study, i.e. 385,420 , and $455 \mathrm{~nm}$. The system was aimed to generate as well as to detect the auto-fluorescence effect of oral cavity in Sprague dawley rats. This study was done in 6 steps, i.e. development of FI system, early test of FI system using coconut oil, palm oil, olive oil, eucalyptus oil, and pure water as samples, followed by finishing of the system, image acquisition of oral cavity autofluorescence from 3 samples of Sprague dawley rats, and the last step was data analysis to determine the best wavelength of HPL for FI system developed in this study. Auto-fluorescence images were obtained by exposing samples by using HPL, then auto-fluorescence effect emitted by samples were captured using Canon EOS D600 camera. Auto-fluorescence intensity from images were analyzed using MATLAB R2008a. Results of this study showed that the best HPL wavelength used for the FI system was $385 \mathrm{~nm}$ that was captured with filter in the camera. The auto-fluorscence image produced by using HPL 385nm was showed the lowest intensities.
\end{abstract}

Keywords: Autofluorescence, Fluorescence Imaging (FI), High Power LED, Oral Cavity, Sprague dawley

\section{INTRODUCTION}

Cancer is one of the most malignancies over the world. In 2012, approximately 14 million new cases of cancer, 8.2 million mortality of cancer, and 32 million adults who have been ever diagnosed within 5 years (WHO, 2016). In southern East Asia, men's risk of being diagnosed with oral or lung cancer is higher than women (WHO, 2016). According to Simanjuntak cit Sirait (2013), cases of oral cancer range between 3-4\% among all cancer, while the mortality from oral cancer is $2-3 \%$ among all malignant (Sirait, 2013).

Early detection of oral cancer is important thing to reduce potentially malignant disorders. It will get a better prognosis on curative therapy, reduce disability, and get a longer survival rate for the sufferer (Lynch et al., 1994). Unfortunately almost all cases of oral cancer were late detected. They were generally diagnosed with advanced stage, who usually have suffered for months or even longer (Lynch et al., 1994), so the survival rate for the sufferer was very low.

The common method used for detecting oral or other cancer currently is screening and biopsy (tissue removal from the human body for histopathological examination) (Avon and Klieb, 2012). However, this method has several disadvantages, such as expensive cost, long and invasive procedure (NCBI, 2013). So, a noninvasive method is required to get early detection of oral cancer, one is autofluorescence properties of the tissues (Qin et.al., 2007). This autofluorescence technology method is indicated as an accurate and potentially applicable to oral disorder, such as dental caries, plaque, calculus, and oral tumours (Köenig KS, 1994 cit Shakibaie et al., 2011). In addition, this method is also effective for detecting pre-cancers in some organs, such as the oral cavity, lungs, and skin (Rahman et al., 2008).

Fluorescence is light emitted by an atom or molecule because of electromagnetic energy absorption (Jameson, 2014). The emitting molecule is called fluorescent molecules or fluorophore. Autofluorescence is a term referred to the intrinsic fluorescence of cells and tissues. When excited with radiation of suitable wavelength, some cell and tissue components behave as an endogenous fluorophores, then they pass to first excited state then decay to the groundstate that have same electron spin while loss of energy, in form of light. It's called fluorescence emission (Monici, 2005). Several important endogenous fluorophores in dental tissues are showed in Table 1.

The autofluorescence effect on oral cavity tissues will be recorded using imaging system, then we called Fluorescence Imaging (FI) system. Technology that utilizes optical properties of tissue by imaging system (optical imaging) can help detect neoplastic lesions in the oral cavity (Rahman et al., 2010). The availability of FI system is expected to help to perform early detection of abnormalities in the oral cavity, so that can be handled better. 
Table 1. Fluorophores and their associated excitation-emission wavelengths for dental tissues (Shakibaie et al, 2011).

\begin{tabular}{|c|c|c|}
\hline $\begin{array}{l}\text { Endogenous } \\
\text { Fluorophore }\end{array}$ & $\lambda$ excitation $(\mathbf{n m})$ & $\lambda_{\text {emission }}(\mathbf{n m})$ \\
\hline Collagen $(I, I I I, V)$ & $300-340$ & $420-260$ \\
\hline Copper & UV light & Orange-Red \\
\hline Coproporphyrin & $398,497,531,565,620$ & 623,690 \\
\hline Cortisol & 475 & 525 \\
\hline Cysteine & 200,349 & 300,707 \\
\hline Elastin & 290,325 & 340,400 \\
\hline FAD, Flavin & 450 & \\
\hline$N A D H$ & 260,340 & 470 \\
\hline$N A D P H$ & 260,340 & 470 \\
\hline Phenylalanine & 257 & 282 \\
\hline Protoporphyrin & $406,505,540,575,630$ & 633,700 \\
\hline Tryptophan & $220,280,288$ & $320-350$ \\
\hline Tyrosine & 220,275 & 305 \\
\hline Uroporphyrin & $404,501,533,568,622$ & 624 \\
\hline Water & 308 & 344,430 \\
\hline Zn-coproporphyrin & $411,539,575$ & 580 \\
\hline Zn-protoporphyrin & $421,548,585$ & 593,646 \\
\hline Apatite & UVC & Bright Pink \\
\hline Hydroxylapatite & UVA and Blue & $\begin{array}{l}\text { Bluish green } \\
\text { and yellow }\end{array}$ \\
\hline
\end{tabular}

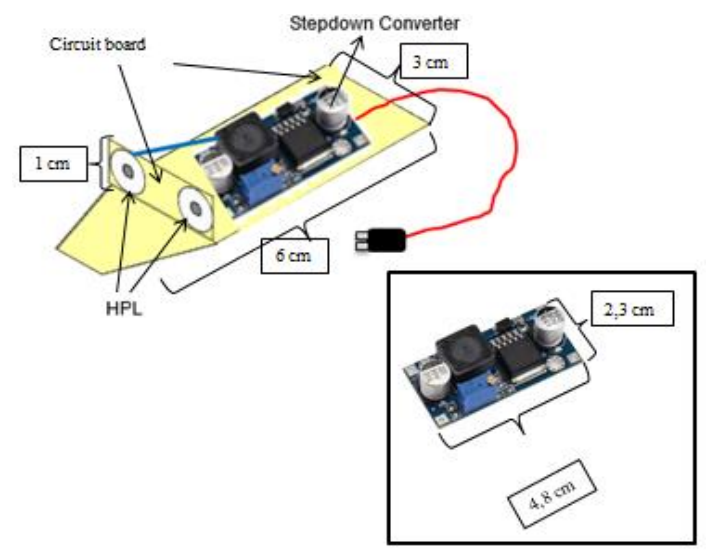

Figure 1. A schematic diagram of Fluorescence Imaging System.

\section{Image Acquisition}

The study was conducted at Integrated Laboratory of UIN Sunan Kalijaga Yogyakarta and Integrated Research Laboratory of Faculty of Denstistry Universitas Gadjah Mada Yogyakarta, Indonesia. The study involved $3 \quad 10 \%$ formalined oral mucoses specimen of Sprague dawley obtained from previous research by Widyaningrum and Gong (2016). Previously, initial FI system examination was carried out on various subtances, i.e., coconut, palm, olive, eucalyptus oil, and pure water of each $1 \mathrm{ml}$. This examination is used to ensure whether the FI system can lead fluorescence effect or not.

\section{MATERIALS AND METHODS}

\section{Instrumentation}

The Fluorescence Imaging (FI) System comprises of three different excitation light wavelength (3 watt HPL $385 \mathrm{~nm}, 420 \mathrm{~nm}$, ULTRA-VIOLET UV Emitter Taiwan EpiSTAR; 3 watt HPL 450-455nm, GROW BLUE Emitter 40-451m, Taiwan EpiSTAR) as an excitation source. A stepdown converter LM2596SDC-DC maximalizes work of HPL with an input current of $3 \mathrm{~A}$. Canon EOS D600 camera combinated with green light filer was used for capturing image of autofluorescence effect. The camera was held at fixed position from the sample using tripod to obtain a stable condition when capturing the image. All materials were placed on a circuit board. The system was connected to a laptop to store and analyze the images using MATLAB R2008a.

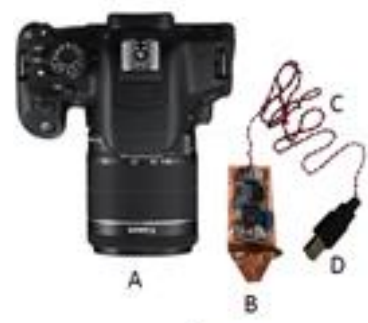

(a)

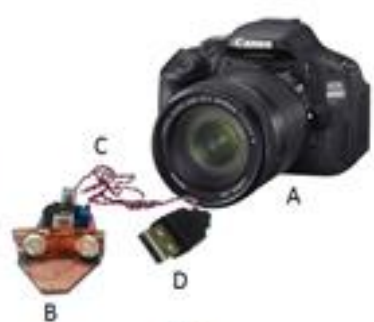

(b)

All image recordings were taken in a darkened room, to avoid interference from ambient light. The excitation source was held at a constant distance $(15 \mathrm{~cm})$. The camera was set at fixed ISO, exposure time, focal length, and auto white balance. It also held at a fixed position from the sample using tripod to obtain a stable condition when capturing the image and at a constant distance $(30 \mathrm{~cm})$ perpendicular to the excitation source. A schematic diagram of image recordings was shown in Fig.2. 


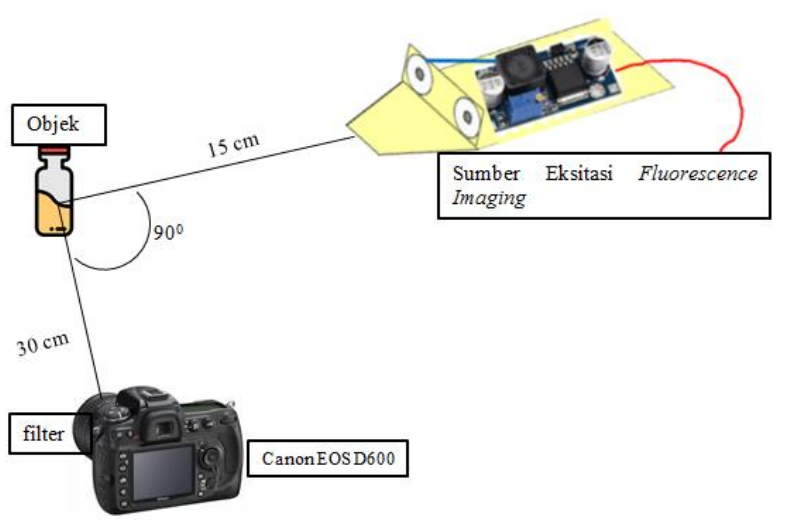

Figure 2. A schematic diagram of image recordings.

Image recording was varied for the excitation source wavelength and use of filter on camera when capturing the image. So, in this stydi there were 6 variations image data, i.e. : image exposed with HPL $385 \mathrm{~nm}$ with and without any filter, image exposed with HPL $420 \mathrm{~nm}$ with and without any filter, and the last image exposed with HPL $455 \mathrm{~nm}$ with and without any filter. The light from excitation source exposured directly to the sample in a short time. Repeatition is applied to each image recording 10 times manually.

\section{Image Analysis}

The autofluorescence images from the camera were a raw file. Then the images were converted to JPG file using "easy2convert WAR to JPG" software. A region of interest (ROI) was selected from the converted image using "Adobe Photoshop" software. Then it will be analyzed by calculating the intensity of autofluorescence using MATLAB R2008a prototype. The MATLAB prototype is shown in Figure 3. Using MATLAB, we calculated the average intensity of each red (R), green (G), and blue (B) channels, average intensity of RGB channels, the average intensity following graysclae conversion, thresholded the image, then we got the intensity of autofluorescence image.

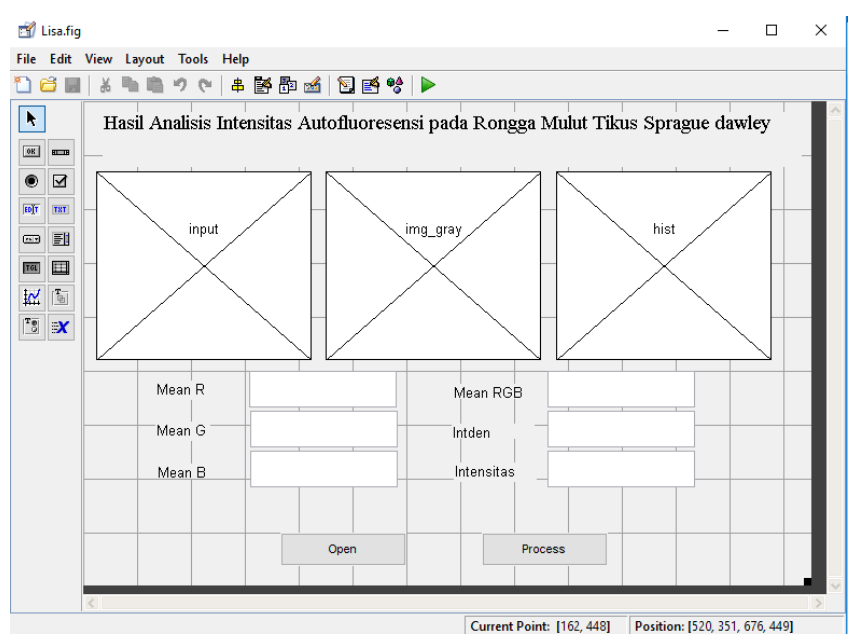

Figure 3. Prototype of image analysis
The method of image data processing using prototype on MATLAB R2008a is as follows:

1. File Open : It was used to get the image to be analyzed

2. Calculating $\mathrm{R}$ mean, $\mathrm{G}$ mean, $\mathrm{B}$ mean, and $\mathrm{RGB}$ mean

3. Image Grayscalling

4. Image Thresholding

5. Calculating autofluorescence image intensity.

In this study, the optimum HPL to generate autofluorescence effect on Sprague dawley oral cavity is HPL that has low intensity based on MATLAB calculation.

\section{RESULTS AND DISCUSSION}

\section{Sprague dawley Image}

Autofluorescence images exposured by 385, 420, and $455 \mathrm{~nm}$ were shown in Table 2. Images which captured by filter combined camera seems darker, so they showed the light-dot clearly than images captured without any filter. The table showed that HPL 385, 420, $455 \mathrm{~nm}$ can generate green autofluorescence effects on around oral mucosa of Sprague dawley. But, the fluorescence dots were on the feather around the oral cavity of the mouse, whereas in the oral cavity the mouse itself showed little autofluorescence.

Table 2. Autofluorescence image esposured by 385, 420, 455 nm HPL.

\begin{tabular}{ll} 
Without Any Filter \\
\hline $385 \mathrm{~nm}$
\end{tabular}

(a)

$420 \mathrm{~nm}$

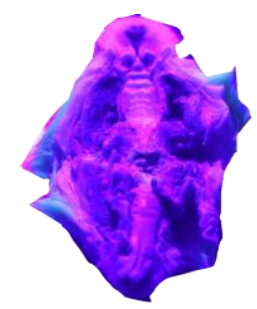

(a)

$455 \mathrm{~nm}$

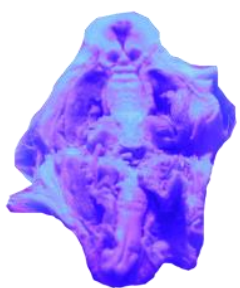

(a)

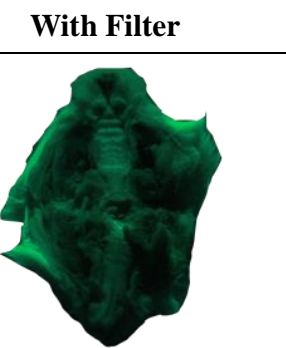

(b)

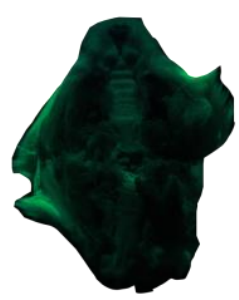

(b)

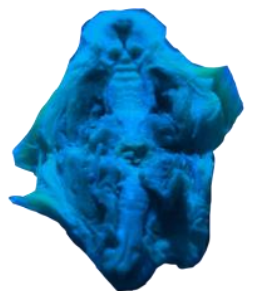

(b) 


\section{Image Autofluorescence Measurement}

The captured autofluorescence images analyzed by the ready matlab prototype. If Fig 3 was run, the process would be in Fig 4. The analyzed image was inputted through prototype, then Matlab will process the image using programming language already written. Thus it will be obtained some parameter values as in table 3 .

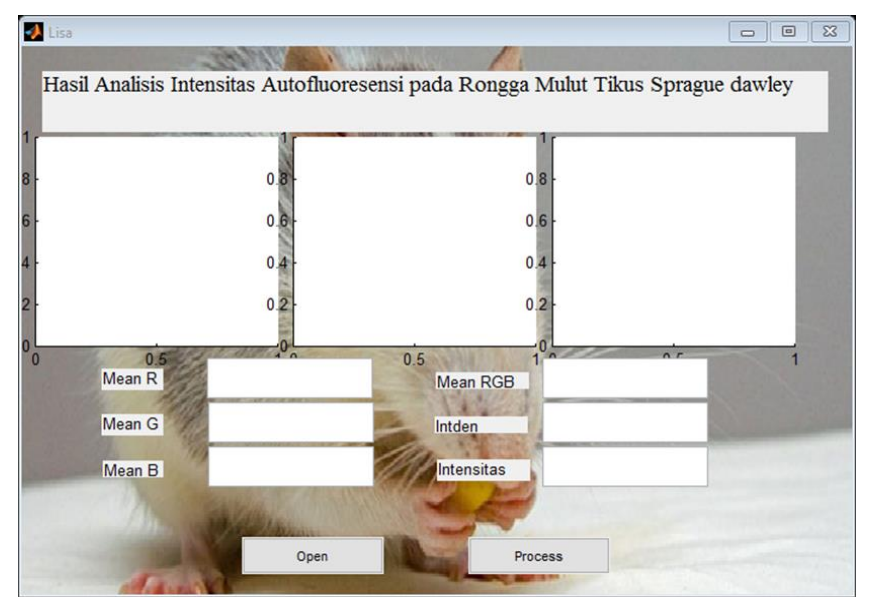

Figure 4. The ready MATLAB Prototype of image analysis.

Table 3. Autofluorescence intensity measurement using MATLAB R2008a on Sprague dawley rat oral cavity with 385 , $420,455 \mathrm{~nm}$ excitation source.

\begin{tabular}{|c|c|c|c|c|c|c|}
\hline \multirow{2}{*}{ No } & \multirow{2}{*}{ Excitation Source } & \multirow{2}{*}{ Variation } & \multicolumn{3}{|c|}{ Autofluorescence Intensity } & \multirow{2}{*}{ Average } \\
\hline & & & Sample 1 & Sample 2 & Sample 3 & \\
\hline \multirow[t]{3}{*}{1} & $385 \mathrm{~nm}$ & Original & 0,184314 & 0,290196 & 0,211765 & 0,228758 \\
\hline & & With filter & 0,035294 & 0,109804 & 0,132157 & 0,092418 \\
\hline & & Without filter & 0,132157 & 0,210196 & 0,231765 & 0,191373 \\
\hline \multirow[t]{3}{*}{2} & $420 \mathrm{~nm}$ & Original & 0,184314 & 0,290196 & 0,211765 & 0,228758 \\
\hline & & With filter & 0,065883 & 0,084314 & 0,135686 & 0,095294 \\
\hline & & Without filter & 0,066667 & 0,287059 & 0,232549 & 0,195425 \\
\hline \multirow[t]{3}{*}{3} & $455 \mathrm{~nm}$ & Original & 0,184314 & 0,290196 & 0,211765 & 0,228758 \\
\hline & & With filter & 0,152941 & 0,184314 & 0,201569 & 0,179608 \\
\hline & & Without filter & 0,250588 & 0,239216 & 0,295294 & 0,261699 \\
\hline
\end{tabular}

\section{Discussion}

In this study, we used HPL 385, 420, and $455 \mathrm{~nm}$ wavelength based on information in Table 1 . The table informs about excitation-emission wavelength of several important endogenous fluorophores in dental tissues, like NADH which has excitaion wavelength of $340 \mathrm{~nm}$, and -emission wavelength of $470 \mathrm{~nm}$; and collagen which has excitation wavelength $300-340 \mathrm{~nm}$ and emission wavelength of 420-460 $\mathrm{nm}$.

The light from HPL exposured directly to the oral mucosa of samples, which contained fluophor molecules (Scheer et al., 2011). Electrons in fluorophore molecules will interact with electromagnetic waves from HPL light. The electrons will be excited then continued with transmission of electromagnetic waves with longer wavelength, so that the sample will generate autofluorescence effect in different intensity at each point (Monici, 2005, Yamamoto et al., 2015)

Overall the lowest intensity of autofluorescence was generated by $385 \mathrm{~nm}$ excitation source with combined filter camera. Intensity is the rate of energy transferred per unit surface, whereas energy is inversely proportional to the wavelength. It shows that the lower the intensity, the wavelength emitted will be higher. In the fluorescence principle, the light generated from the fluorescence process has a higher wavelength. Thus, the most optimum FI system to generate autofluorescence of the Sprague dawley's oral was $385 \mathrm{~nm}$ wavelength excitation source with combined filter camera. From the data analysis on each excitation source wavelength the autofluorescence effect of Sprague dawley's oral cavity generate a blue-green color. It was consistent with the theory of fluorescence, when an object is illuminated by a suitable wavelength excitation source, in this case was UV light and blue light (wavelength of 380-450 nm), it will produce a longer wavelength, Which is a blue-green light (wavelength 450-495 nm).

\section{CONCLUSIONS}

Results of this study showed that the best HPL wavelength used for the FI system was $385 \mathrm{~nm}$ that was captured with filter in the camera. The auto-fluorscence image produced by using HPL $385 \mathrm{~nm}$ was showed the lowest intensities. 


\section{REFERENCES}

Avon, S. L., \& Klieb, H. B. E. 2012. Oral soft-tissue biopsy: An overview. Journal of the Canadian Dental Association, Vol.78 No.1 2012: 1-9

Jameson, D. M, 2014, Introduction to Fluorescence, CRC Press, Boca Raton

Lynch, M.A., Brigthman, V.J., Greenberg, M.S., 1994, Burket's oral medicine: Diagnosis and treatment, Philadelphia, Lippincott

Monici, M. 2005. Cell and tissue autofluorescence research and diagnostic applications. Biotechnology Annual Review, vol.11 $2005: 227-256$

NCBI. 2016. Benefits and risks of screening tests. https://www.ncbi.nlm.nih.gov/pubmedhealth/PMH0072602/

Qin, Y. L., Luan, X. L., Bi, L. J., Lü, Z., Sheng, Y. Q., Somesfalean, G.,Zhang, Z. G. (2007). Real-time detection of dental calculus by blue-LED-induced fluorescence spectroscopy. Journal of Photochemistry and Photobiology B: Biology, Vo.87 no.2 Maret 2007:88-94

Rahman, M., Chaturvedi, P., Gillenwater, A. M., \& RichardsKortum, R. 2008. Low-cost, multimodal, portable screening system for early detection of oral cancer. Journal of Biomedical Optics, Vo.13 No.3 Juni 2008 : 30502-1 s.d 30502-3
Rahman, M. S., Ingole, N., Roblyer, D., Stepanek, V., RichardsKortum, R., Gillenwater, A., Chaturvedi, P. 2010. Evaluation of a low-cost, portable imaging system for early detection of oral cancer. Head Neck Oncol, Vol.2 No.10 2010 : 1-8

Shakibaie, F., George, R. and Walsh, L. J. 2011. Applications of Laser induced Fluorescence in Dentistry, International Journal of Dental Clinics, Vol.3 No.3 Januari 2011 : 38-44.

Shakibaie, F. and Walsh, L. J. 2016. Violet and blue light-induced green fluorescence emissions from dental caries, Australian dental journal, Vol.61 No.4 Januari 2016 : 464-468.

Sirait, A. M. (2013). Faktor Risiko Tumor / Kanker Rongga Mulut dan Tenggorokan di Indonesia ( Analisis Riskesdas 2007 ). Media Litbangkes XXIII, Nomor 3 Tahun 2013 : 1229.

WHO, 2016. Cancer. http://www.who.int/cancer/en/

WHO, 2016. All Cancers (excluding non-melanoma skin cancer) Estimated Incidence, Mortality and Prevalence Worldwide in 2012. http://globocan.iarc.fr/Pages/fact_sheets_cancer.aspx

Widyaningrum, R. dan Matua,G. 2016. Pengembangan Pencitraan Fotoakustik sebagai Modalitas Pencitraan Medik untuk Pemeriksaan Jaringan Lunak Mukosa Rongga Mulut. (Laporan Hibah Penelitian Dosen), FKG, UGM. 
THIS PAGE INTENTIONALLY LEFT BLANK 